\title{
KELOMPOK KEPENTINGAN DAN RELASI KUASA DALAM PENGELOLAAN SUMBER DAYA LAUT PALABUHANRATU
}

\section{Group of Interest and Relation Power in The Utilization of Marine Resources Palabuhanratu}

\author{
*Eva Royandi, Arif Satria dan Saharuddin \\ Fakultas Ekologi Manusia, Institut Pertanian Bogor (IPB). \\ Kampus IPB Dramaga, Jalan Kamper, Babakan, Dramaga, Bogor, Jawa Barat, Indonesia \\ Diterima tanggal: 22 Juni 2018 Diterima setelah perbaikan: 8 Nopember 2018 \\ Disetujui terbit: 26 Desember 2018 \\ *email: e.royandi@yahoo.co.id
}

\begin{abstract}
ABSTRAK
Tujuan penelitian ini adalah menganalisis aktor dan relasi kekuasaan yang terjadi dalam pengelolaan sumber daya laut Palabuhanratu. Lokasi penelitian di Perairan Laut Palabuhanratu, Sukabumi, Jawa Barat. Penelitian menggunakan metode kualitatif. Hasil penelitian menunjukkan bahwa semua aktor membangun kekuasaan melalui mekanisme akses berbasis hak dan mekanismes akses berbasis struktur dan relasi sosial dengan basis kekuasaan modal, pasar, teknologi, pengetahuan, identitas sosial, otoritas, dan patron klien. Kelompok nelayan lokal, nelayan dari luar (nelayan Banten) dan nelayan pendatang etnis Jawa berupaya mempertahankan akses, sementara kelompok nelayan etnis Bugis berupaya mengontrol akses terhadap sumber daya laut. Perbedaan posisi antar kelompok nelayan menyebabkan terjadinya relasi kekuasaan antar kelompok nelayan dalam memperoleh sumber daya laut Palabuhanratu. Sementara aktivitas pihak pengelola PLTU dianggap membatasi kekuasaan kelompok nelayan melalui penggunaan wilayah pesisir dan penggunaan jalur transportasi laut. Keterbatasan akses kelompok nelayan menyebabkan terjadinya relasi kuasa antara nelayan dengan pengelola PLTU.
\end{abstract}

Kata Kunci: aktor; akses; relasi kekuasaan

\section{ABSTRACT}

The purpose of this study is to analyze the actors and power relations occured in the management of Palabuhanratu marine resources. Research was located in Palabuhanratu Sea Waters, Sukabumi, West Java. Research used qualitative methods. Results of the study showed that all actors built power through right-based access mechanisms and mechanisms based on structure and social relations with a basis of power of capital, markets, technology, knowledge, social identity, authority, and patron clients. Local fishing groups, outside fishers (Banten fishers) and Javanese ethnic fishers tried to maintain access, while Bugis ethnic fishers groups tried to control access to marine resources. Differences in position between fishers groups led to power relations among the groups in obtaining Palabuhanratu marine resources. While the activities of the management of the Steam Power Plant (PLTU) were considered to limit the power of fishers groups through the use of coastal areas and sea transportation routes. Limited access of fishers groups led to power relations between fishers and managers of Steam Power Plants (PLTU).

Keywords: actors; access; power relations

\section{PENDAHULUAN}

Perairan laut Indonesia memiliki potensi lestari sumber daya ikan atau Maximum Sustainable Yield (MSY) sebesar 7.3 juta ton per tahun, dengan jumlah tangkapan yang diperbolehkan atau Total Allowable Catch (TAC) sebesar 5.4 juta ton pada tahun 2013 atau baru
93 persen dari TAC. Total produksi perikanan mikro flora-fauna kelautan belum tereksplorasi secara penuh sebagai penyangga pangan fungsional pada masa depan (BPS, 2016). Potensi lestari perairan laut yang dimiliki Indonesia tentunya memiliki ketergantungan pada laut yang sehat (Satria, 2015). Akan tetapi, terdapat berbagai isu permasalahan yang 
berkairan dengan sumber daya perairan laut, yaitu; kerusakan lingkungan, keberlanjutan sumber daya alam, keberlanjutan mata pencaharian masyarakat nelayan, dan beberapa wilayah perairan laut Indonesia yang telah mengalami gejala overfishing (DKP, 2014). Isu lainnya, yaitu; munculnya praktik-praktik Illegal, Unregulated and Unreported (IUU) Fishing di wilayah perairan laut Indonesia, sehingga dapat menyebabkan kerugian baik dari aspek sosial, ekologi/lingkungan, dan ekonomi (DKP, 2014). Selain itu, isu kerusakan sumber daya kelautan dan perikanan, diakibatkan oleh praktik-praktik penangkapan dan pembangunan pesisir yang tidak pro terhadap lingkungan.

Kelimpahan dan kekurangan sumber daya alam (sumber daya laut) sering terjadi meningkatkan resiko konflik sosial (Wegenast \& Schneider, 2016). Potensi sumber daya perikanan tangkap di Indonesia cenderung berkurang, sehingga menyebabkan sering terjadinya konflik di antar kelompoknelayan maupun kelompok nelayan dengan non-nelayan (Kinseng, 2007). FAO (2000) adanya konflikkonflik yang secara terus-menerus berkaitan dengan sumber daya alam, salah satunya sumber daya kelautan dan perikanan akan menyebabkan munculnya degradasi lingkungan, menghambat pembangaunan, dan secara langsung maupun tidak langsung dapat mengganggu berbagai tatanan kehidupan yang sudah terbangun di masyarakat. Buckles (1999) terdapat empat penyebab timbulnya konflik pengelolaan sumber daya alam termasuk sumber daya perairan laut yaitu: Pertama, adanya perbedaan akses antar aktor sosial dan/atau institusi terhadap pusat kekuasaan. Kedua, aktivitas manusia yang mengubah keseimbangan ekosistem di suatu wilayah dapat menimbulkan masalah lingkungan di wilayah lainnya. Ketiga, adanya peningkatan kalangkaan sumber daya alam (natural resources scarcity) yang disebabkan oleh terjadinya perubahan lingkungan, pertumbuhan penduduk dan peningkatan permintaan, serta pola pendistribusian yang tidak merata. Keempat, sumber daya alam dipergunakan oleh manusia bukanlah semata mata sebagai material yang diperebutkan, namun juga untuk mendefinisikan hidupnya secara simbolis. Penyebab konflik yang dinyatakan Buckles (1999) ada kemiripin dengan sebab-sebab terjadinya relasi kekuasaan antara kelompok nelayan maupun antara nelayan dengan pengelola PLTU dalam pengelolaan dan pemanfaatan sumber daya laut yang terjadi di Palabuhanratu.
Relasi kekuasaan di antara para aktor yang tidak setara merupakan dampak dari politisasi lingkungan (politicized environment) (Bryant dan Bailey, 1997). Politisasi lingkungan adalah adanya pusat kekuasaan atau dominasi aktor negara dan swasta terhadap sumber daya alam. Akibat dari dominasi tersebut, membatasi akses bagi sebagain aktor lainnya, terutama aktor akar rumput yaitu aktor lokal (Bryant dan Bailey, 1997). Akhirnya, muncul asumsi (hipotesis) baru yang diungkapkan Bryant dan Bailey (1997, 1999): Pertama, biaya dan manfaat yang berhubungan dengan perubahan lingkungan didistribusikan di antara berbagai aktor secara tidak merata. Kedua, distribusi biaya dan manfaat yang tidak merata dapat menyebabkan terjadinya berbagai ketimpangan sosial ekonomi. Ketiga, akibat adanya berbagai ketimpangan sosial ekonomi, akhirnya merubah berbagai relasi kuasa di antara aktoraktor. Aktor-aktor dalam perspektif Bryant \& Bailey (1997) yaitu; Pertama, Negara (The State), Kedua, Lembaga multilateral (Multilateral Environment), Ketiga, Bisnis (Business), Keempat, NGO lingkungan (Environmental Non-Governmental Organisations), dan Kelima, Aktor akar rumput (Grassroots Actors). Relasi kuasa diantara aktor berkaitan dengan kekuasaan aktor untuk mengontrol, memperoleh, dan mempertahankan aksesnya terhadap sumber daya (Ribot \& Peluso, 2003). Relasi kuasa yang terjadi dalam pengelolaan sumber daya laut Palabuhanratu yaitu relasi kuasa antar kelompok nelayan dalam memperoleh sumber daya laut yang memiliki nilai sosial, ekonomis, budaya dan politik. Selain itu, relasi kuasa terjadi antara kelompok nelayan karena adanya perbedaan alat tangkap, wilayah penangkapan yang sama dan adanya pembatasan akses oleh pihak Industri (pengelola PLTU) sebagai aktor baru. Kurniawan (2012) PLTU telah membatasi ruang gerak atau akses nelayan untuk melakukan kegiatan penangkapan ikan. Akibatnya, respon politik yang dilakukan oleh kelompok nelayan berupa perlawanan-perlawanan terhadap pihak PLTU Palabuhanratu.

Penelitian dilakukan di Pelabuhan Perikanan Nusantara (PPN) Pelabuhanratu, Kabupaten Sukabumi, Provinsi Jawa Barat. Pemilihan lokasi penelitian didasarkan pada beberapa pertimbangan sosial, ekonomi, budaya dan karakteristik sumber daya kelautan dan perikanan. Permasalahan antar kelompok nelayan karena adanya indikasi kelangkaan sumber daya, dominasi nelayan 
pendatang dan pelanggaran-pelanggaran aturan dalam melakukan aktivitas penangkapan ikan. selain itu, nelayan berhadapan dengan terbatasnya akses nelayan terhadap sumber daya laut, karena diakibatkan adanya aktivitas PLTU yang menggunakan wilayah pesisir dan laut Palabuhanratu. Penelitian dialakukan mulai dari April 2017- Pebruari 2018. Penelitian menggunakan metode kualitatif.

Analisis data kualitatif dengan menggunakan model interaktif yang terdiri dari tiga hal utama yaitu; Pertama, reduksi data (proses pemilihan data); Kedua, penyajian data; dan Ketiga, penarikan kesimpulan/verifikasi. Ketiga proses analisis tersebut merupakan proses kegiatan yang jalin-menjalin secara terus-menerus pada saat sebelum, selama, dan sesudah pengumpulan data dalam membuat laporan penelitian (Miles dan Huberman, 1992). Reduksi data merupakan tahap pengumpulan data yang sudah memasuki proses lingkungan penelitian dan melakukan pengumpulan data penelitian. Proses reduksi data di mana adanya proses pemilihan data yang dilakukan sejak peneliti berada di lapangan. Tahap penyajian data di mana penyajian informasi dapat digunakan untuk memberikan kemungkinan adanya penarikan kesimpulan sehingga tahap ini dapat berupa matriks analisi, bagan, gambar dan tabel analisis. Kemudian, tahap penarikan kesimpulan dari data yang sudah ada dapat dilakukan suatu verifikasi lapangan. Penelitian ini menggunakan pendekatan aktor Bryant dan Bailey (1997) yang memberikan penjelasan peran dan kepentingan aktor terhadap sumber daya laut Palabuhanratu. Akan tetapi, dalampendekatan aktor tidak menggunakan aktor Lembaga multilateral (Multilateral Environment). Pendekatan aktor dikombinasikan dengan teori akses Ribot dan Peluso (2003) dan teori perlawanan Scott (1990). Teori akses Ribot dan Peluso (2003), memberikan kontribusi terhadap analisis relasi kuasa, karena menempatkan kekuasaan di dalam konteks politik ekonomi yang dapat membentuk kemampuan orang (kekuasaan aktor) dalam memanfaatkan sumber daya. Definisi akses sebagai bundle dan jaring kekuasaan yang memungkinkan aktor mendapatkan, mengendalikan, dan memelihara akses. Akses dapat diartikan sebagai suatu kemampuan untuk memperoleh keuntungan dari sesuatu (Ribot dan Peluso, 2003). Misalnya, kemampuan untuk mendapatkan keuntungan dari objek material, orang, lembaga, dan simbol (Ribot dan Peluso, 2003). Kemampuan tersebut berkaitan dengan kekuasaan, di mana kekuasaan melekat dan dilaksanakan melalui berbagai mekanisme, proses, dan relasi sosial, modal, pasar, penguasaan teknologi, tenaga kerja, dan peluang kerja, pengetahuan, kewenangan, identitas sosial, dan relasi sosial (bundle of power) akan memengaruhi tingkat akses terhadap pemanfaatan dan pengelolaan sumber daya (Ribot \& Peluso, 2003). Relasi kekuasaan antar berbagai aktor dalam memperoleh sumber daya dapat terjadi dalam bentuk konfliktual, negosiasi dan perlawanan (Bryant \& Bailey, 1997; Ribot \& Peluso. 2003; dan Scott, 1990).

\section{SEJARAH PENGELOLAAN SUMBER DAYA LAUT PALABUHANRATU}

Kawasan Palabuhanratu sebelum tahun 1980 masih merupakan suatu desa nelayan dengan produktivitas produksi rendah serta memiliki tingkat kerawanan sosial, ekonomi, budaya, politik, dan pertahanan keamanan yang cukup tinnggi. Sedangkan dari segi strategis pertahanan keamanan territorial sangat mendukung terjadi intervensi kewilayah kelautan Republik Indonesia baik dari Negara lain ataupun dari bangsa Indonesia sendiri (Statistik PPN Palabuhanratu 2017). Tahun 1960-an banyak nelayan pendatang seperti dari Cirebon, Cilacap dan Sulawesi Selatan untuk ikut serta dalam memperoleh sumber daya laut Palabuhanratu. Melihat kondisi nelayan yang sangat direpotkan oleh kebutuhan tempat bongkar, mendaratkan ikan, memasarkan ikan yang layak, serta keamanan perahu yang terjamin saat istirahat terhadap hantaman gelombang terutama pada musim barat serta dengan pemikiran adanya potensi perikanan di sekitar Palabuhanratu maka dibangunlah Pelabuhan Perikanan Nusantara (PPN) Palabuhanratu. Pembangunan fisik pelabuhan dilaksanakan pada Tahun Anggaran 1991/1992 sampai dengan Tahun Anggaran 1992/1993 dan pada tanggal 18 Februari 1983 diresmikan operasionalnya oleh Prisiden RI (Soeharto). Selain dimanfaatkan kapal perikan domisili, segenap fasilitas PPN Palabuhanratu dapat dimanfaatkan oleh nelayan dari luar (nelayan Banten). Adanya kelompok nelayan lokal, nelayan pendatang, nelayan dari luar dan pihak pemerintah dan pihak industri (pengelola PLTU), menyebabkan persaingan dalam memperoleh sumber daya laut mengarah kepada relasi kuasa yang berbentuk konfliktual, negosiasi dan perlawanan. sejarah pengelolaan sumber daya laut Palabuhanratu terdapat dalam Gambar 1. 


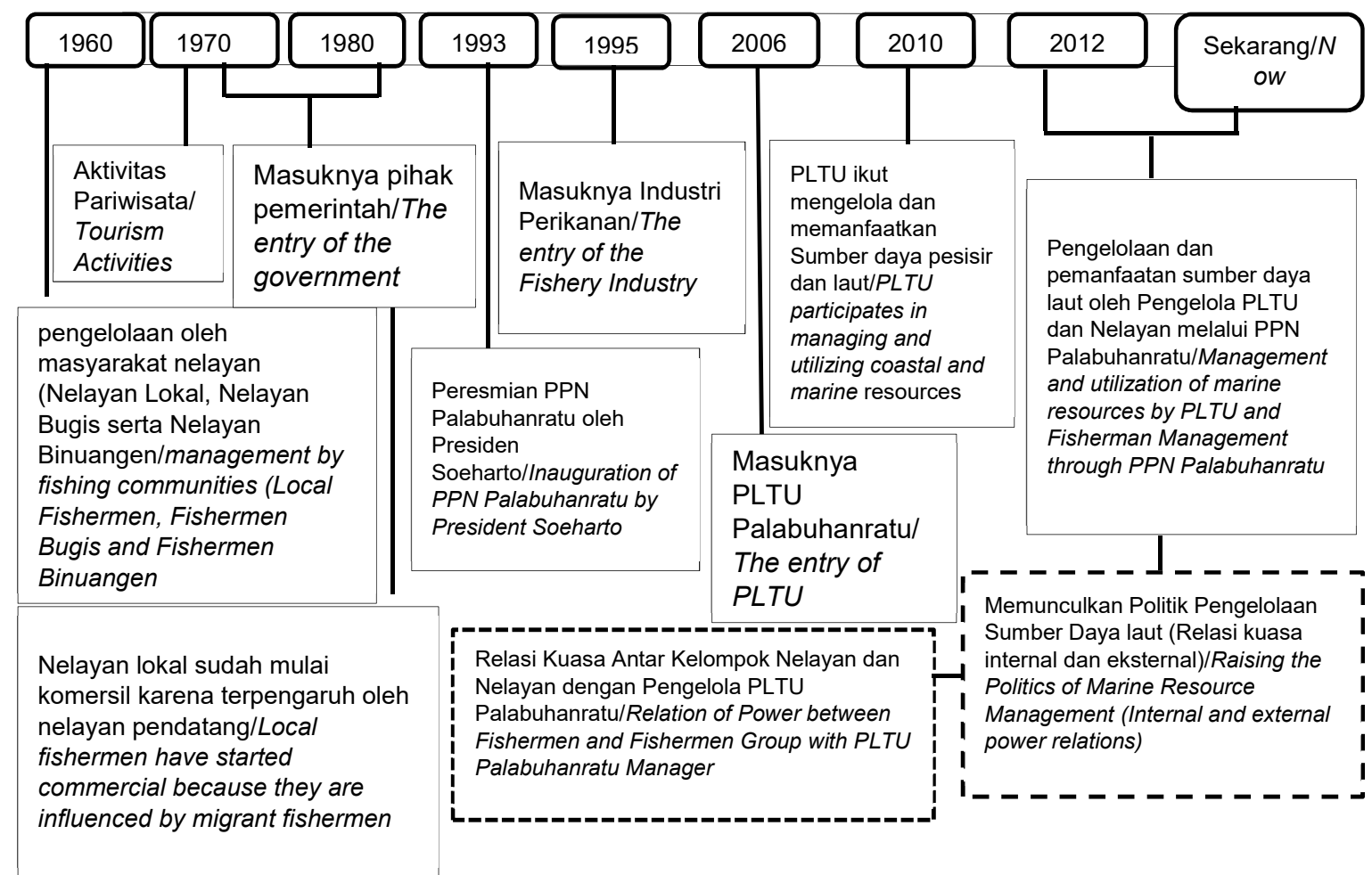

\section{Gambar 1. Sejarah Pengelolaan dan Pemanfaatan Sumber Daya Laut Palabuhanratu. Figure 1. Historical Resources Management and Utilization of Marine Palabuhanratu.}

\section{KEKUASAAN AKTOR UNTUK MENGAKSES SUMBER DAYA LAUT}

Ada dua mekanisme terbentuknya akses menurut Ribot dan Peluso (2003) yaitu, Pertama, mekanisme right-based access (akses berbasis hak), sperti adanya ketetapan hukum melalui Undang-undang, hukum adat istiadat, dan konvensi atau kesepakatan yang terbentuk dari keputusan diantara aktor. Akses legal, ditentukan berdasarkan hukum, adat, dan konvensi. Sedangkan akses ilegal beroprasi melalui paksaan (melalui kekerasan atau ancaman) dan diam-diam membentuk hubungan diantara aktor yang mencoba untuk mendapatkan, mengendalikan, atau mempertahankan akses. Kedua, mekanisme structural and relational access (akses relasional dan struktural) yaitu, kemampun untuk mendapatkan keuntungan dari sumber daya yang dibingkai politik-ekonomi dan budaya. Mekanisme struktural dan relasi sosial melalui basis kekuasaan yang terdiri dari Teknologi, pengetahuan, modal, otoritas, identitas sosial dan relasi sosial dalam bentuk rasa saling percaya, persahabatan dan rasa tanggungjawab.

\section{a. Nelayan Lokal}

Nelayan lokal memainkan kekuasaan yang dibangun melalui mekanisme hak, baik secara legal dengan mendapatkan suarat izin dari pihak otoritas yaitu PPN Palabuhanratu dan dinas Kelautan dan Perikanan Kabupaten Sukabumi. Kekuasaan yang dibangun melalui mekanisme akses menjadi modal dasar bagi nelayan lokal, selain posisinya sangat diuntungkan sebagai nelayan asli dari wilayah Palabuhanratu.

Kekuasaan yang dibangun melalui mekanisme struktural dan realsional dengan memanfaatkan identitasnya sebagai nelayan pribumi, bagi nelayan lokal sumber daya laut Palabuhanratu merupakan hak bagi mereka, karena sudah secara turun-temurun dikelola secara tradisional dan secara moderen dalam memanfaatkan dan mengelola sumber daya laut.

\section{b. Nelayan Pendatang (etnis Bugis)}

Nelayan pendatang memiliki kekuatan relasi sosial baik berupa patronase maupun dominasi terhadap nelayan lokal, bukti dari dominasi tersebut dari hasil observasi bahwa nelayan pendatang 
seperti etnis Bugis lebih mengusai wilayah laut di Palabuhanratu bahkan mereka mengusai wilayah laut untuk digunakan alat tangkap rumpon dan semuanya menggunakan nelayan dari etnis Bugis. Selain itu, dalam catatan sejarah banyak nelayan lokal yang belajar kepada nelayan bugis dalam melakukan aktivitas penangkapan ikan. Proses belajar cara menangkap ikan kepada etnis Bugis dengan banyaknya alat tangkap bagan yang di manfaatkan oleh nelayan lokal sebagai hasil dari karya etnis bugis di wilayah laut Palabuhanratu, sehingga hubungan sosial tersebut memberikan peluang terhadap adanya hubungan dominasi dari nelayan pendatang kepada nelayan lokal.

Budaya nelayan lokal yang belum mampu untuk dapat melaut lebih jauh dan berhari-hari. Apabila diperhatikan bahwa nelayan lokal masih bertahan dengan melaut satu hari satu malam bahkan hanya satu malam mereka mampu menangkap ikan ke laut, sehingga sudah menjadi budaya nelayan lokal di Palabuhantau. Kebiasaan nelayan lokal yang belum mampu berubah dapat dimanfaatkan oleh nelayan pendatang etnis Bugis yang memiliki modal, pengetahuan, dan teknologi yang lebih canggih.

\section{c. Nelayan Dari Luar (Nelayan Banten)}

Kekuasaan nelayan dariluar (nelayan Banten) yang dibangun melalui mekanisme Berbasis Hak. Mekanisme berbasis hak dengan mendapatkan perizinan secara legal dari pihak pemerintah melalui lembaga Pelabuhan Perikanan Nusantara (PPN) Palabuhanratu (sebagai perwakilan dari pemerintah pusat) dan Dinas Kelautan dan Perikanan Kabupaten Sukabumi (sebagai perwakilan dari pemerintah daerah) untuk menangkap ikan dan bongkar ikan di wilayah Palabuhanratu. Dengan demikian, pemanfaatan sumber daya kelautan dan perikanan di Palabuhanratu tidak bertentangan dengan aturan-aturan pihak pemerintah. Dengan mendapatkan hak secara legal kelompok nelayan dari luar

Kekuasaan nelayan dari luar (nelayan Banten) yang dibangun melalui mekanisme Struktural dan Relasional dengan menggunakan basia kekuasaan pada relasi sosial antara nelayan dari luar dengan nelayan lokal dan nelayan pendatang (nelayan pendatang etnis Jawa dan etnis Bugis. Hubungan relasi sosial dapat berbentuk hubungan tengkulak(pemilik modal), Tawe (pemilik kapal) dengan buruh nelayan dalam proses memperoleh sumber daya ikan. Hubungan sosial yang terjalin dapat berupa rasa saling percaya, tanggungjawa dan patronase diantara tengkulak-tawe-buruh nelayan dari nelayan Banten dengan nelayan di Palabuhanratu. Basis kekuasaan identitas sosial yang berupa identitasnya sebagai etnis Sunda dan sesama nelayan.

\section{d. Pengelola PLTU}

Pengelola PLTU Palabuhanratu yang secara resmi mendapatkan surat ijin dari pemerintahpada tahun 2006. Rencana awal pembangunan PLTU Palabuhanratu di wilayah Ujung Genteng Sukabumi, tetapi mendapatkan penolakan dari pihak masyarakat, sehingga pemerintah pusat dan daerah mengalihkan tempat pembangunan PLTU di wilayah Palabuhanratu. walaupun, mendapatkan penolakan dari masyarakat nelayan, pihak pemerintah berhasil melakukan negosiasi dengan kelompok nelayan melalui kekuasaan legal dan otoritasnya. Pihak PLTU membangun basis kekuasaan dengan menggunakan modal yang dimilikinya, dimana nelayan banyak yang mendapatkan bantuan berupa alat tangkap dan biaya ibu-ibu nelayan untuk membuat usaha abon ikan.

\section{RELASI KUASA ANTAR AKTOR DALAM PENGELOLAAN SUMBER DAYA LAUT PALABUHANRATU}

Relasi kekuasaan dapat terjadi dalam bentuk konflik atau kompetisi, kerjasama (negosiasi) dan perlawanan dalam memperoleh manfaat dari sumber daya (Ribot dan Peluso 2003, Bryant dan Bailey 1997, 2015, dan Scott 1990). Konflik atau kompetisi tentunya akan dimenangkan oleh aktor yang memiliki bundle of power yang lebih besar dibandingkan aktor lainnya. Aktor yang memiliki kekuasaan lebih banyak dapat mempengaruhi aktor lain dalam mengontrol, mempertahankan (memanfaatkan), dan memelihara sumber daya laut (Febryano et al., 2015; Priyatna et al., 2013). Relasi kekuasaan dalam pengelolaan sumber daya perairan laut Pelabuhanratu, setidaknya terdapat beberapa aktor yang saling berinteraksi, yaitu: Nelayan lokal, Nelayan Pendatang Etnis Bugis, Nelayan Pendatang Etnis Jawa, Nelayan dari Luar (Nelayan Banten), Pelabuhan Perikanan Nusantara (PPN) Palabuhanratu, Kementrian Kelautan dan Perikanan, Dinas Perikanan dan Kelautan Kabupaten Sukabumi, Wisata Bahari, PLTU Pelabuhanratu, PT. Indonesia Power, dan Kementerian Badan Usaha Milik Negara (BUMN). 
Tabel 1. Kekuasaan Aktor dalam Mengakses Sumber Daya Laut Palabuhanratu. Table 1. The Power of Actors in Accessing the Marine Resources of Palabuhanratu.

\begin{tabular}{|c|c|c|c|}
\hline Aktor/Actor & Kepentingan/Interests & $\begin{array}{l}\text { Mekanismes Akses/ } \\
\text { Mechanisms of Access }\end{array}$ & $\begin{array}{l}\text { Kekuasaan Aktorl } \\
\text { The Power of Actor }\end{array}$ \\
\hline $\begin{array}{l}\text { Nelayan lokal/ } \\
\text { Local Fishers }\end{array}$ & $\begin{array}{l}\text { Pemanfaatan wilayah laut } \\
\text { dan pesisir/Utilization of } \\
\text { marine and coastal areas }\end{array}$ & $\begin{array}{l}\text { Berbasis Hak, Struktural Dan } \\
\text { Relasional/Rights-Based, } \\
\text { Structural and Relational }\end{array}$ & $\begin{array}{l}\text { Kekuasaan Identitas dan } \\
\text { Relasi Sosial/The power of } \\
\text { identity and social relations }\end{array}$ \\
\hline $\begin{array}{l}\text { Nelayan pendatang/ } \\
\text { Fishers Newcomer }\end{array}$ & $\begin{array}{l}\text { Memanfaatkan wilayah laut } \\
\text { dan pesisir/Utilization of } \\
\text { marine and coastal areas. }\end{array}$ & $\begin{array}{l}\text { Berbasis Hak, Struktural dan } \\
\text { Relasional/Rights-based, } \\
\text { structural and relational }\end{array}$ & $\begin{array}{l}\text { Menjalin relasi dengan } \\
\text { pihak otoritas, Relasi } \\
\text { sosial dan Pengetahuan/ } \\
\text { Establish relationships with } \\
\text { authorities, Social Relations } \\
\text { and Knowledge }\end{array}$ \\
\hline $\begin{array}{l}\text { Nelayan dari luar/ } \\
\text { Fishers From } \\
\text { Outside }\end{array}$ & $\begin{array}{l}\text { Penangkapan ikan dan } \\
\text { bongkar ikan/Fishing and } \\
\text { Unloading Fish }\end{array}$ & $\begin{array}{l}\text { Berbasis Hak, Struktural dan } \\
\text { Relasional/ Rights-Based, } \\
\text { Structural and Relational }\end{array}$ & $\begin{array}{l}\text { Menjalin relasi dengan } \\
\text { pihak otoritas/ Establish } \\
\text { relationships with authorities, } \\
\text { Capital, Technology and } \\
\text { identity }\end{array}$ \\
\hline $\begin{array}{l}\text { Pengelola PLTU/ } \\
\text { PLTU Manager }\end{array}$ & $\begin{array}{l}\text { Transportasi laut dan } \\
\text { pembangunan PLTU/ } \\
\text { Marine transportation and } \\
\text { construction of PLTU }\end{array}$ & $\begin{array}{l}\text { Berbasis Hak, Struktural dan } \\
\text { Relasional/ Rights-Based, } \\
\text { Structural and Relational }\end{array}$ & $\begin{array}{l}\text { Menjalin relasi dengan pihak } \\
\text { Otoritas dan modal/ Establish } \\
\text { relationships with authorities } \\
\text { and Capital }\end{array}$ \\
\hline
\end{tabular}

Pengelolaan dan pemanfaatan sumber daya laut di wilayah Palabuhanratu telah menggambarkan formasi relasi kuasa yang kompleks. Terjadinya relasi kuasa yang kompleks karena setiap aktor memiliki kepentingankepentingan yang berbeda terhadap sumber daya laut Palabuhanratu. Sejak tahun 1960, diawali dengan datangnya etnis bugis ke wilayah laut Palabuhanratu, kepentingan yang berbedabeda sudah ada antara nelayan lokal dengan nelayan pendatang. Nelayan lokal awalnya hanya memanfaatkan ikan dengan memancing, tetapi setelah etnis Bugis memperkenalkan Bagan, Nelayan lokal mulai melakukan kerjasama dan belajar memanfaatkan sumber daya laut. Kemudian setelah tahun 1980 dan tahun 1993 pengelolaan sumber daya laut di Palabuhanratu semakin kompleks dengan peran sertanya pihak pemerintah dan industri perikanan. Tahun 2006 hadir Pengelola PLTU sebagai aktor baru yang ikut andil dalam kontestasi pengelolaan dan pemanfaatan sumber daya laut di wilayah Palabuhanratu.

\section{a. Relasi Kuasa Nelayan Lokal dan Nelayan Pendatang (Etnis Bugis)}

Relasi Kuasa Nelayan Lokal dan Nelayan Pendatang terjadikarena nelayan lokal menganggap bahwa mereka yang lebih berhak dalam melakukan pengelolaan dan pemanfaatan sumber daya laut palabuhanratu. Walaupun, sistem pengelolaan dan pemanfaatan sumber daya laut Palabuhanratu sudah dikuasai oleh sistem pemerintah negara Republik Indonesia, tetapi, sebagai nelayan lokal tetap masih memelihara tatakrama atau aturan lokal bahwa setiap nelayan pendatang harus tetap menghargai nelayan lokal yang memiliki wilayah laut palabuhanratu secara informal. Akhirnya, muncul respon dari nelayan lokal akibat peberdaan kepentingan dalam memanfaatkan wilayah laut Palabuhanratu, sehingga pada tahun 1990 konflik antara nelayan lokal dengan nelayan pendatang sudah mulai terjadi, terutama berkaitan dengan masalah pemanfaatan wilayah laut untuk alat tangkap rumpon. Karena wilayah rumpon ini masih tetap dalam kendali nelayan pendatang, bahkan terdapat juragan nelayan dari etnis bugis yang memiliki 10 Kapal khusus alat tangkap Rumpon yang setiap kapal ada 5 orang termasuk pengemudi dan Anak Buah Kapal (ABK) semuanya berasal dari Sulawesi tanpa menggunakan nelayan lokal. Sebagai responnya, terjalin hubungan konfliktual antara pihak yang berkeinginan memanfaatkan alat tangkap rumpon dengan nelayan yang tidak menginginkan alat tangkap rumpon, tetapi masih dengan catatan boleh ada rumpon tetapi harus ada kebijakan yang menyatakan bahwa nelayan lokal harus ikut berpartisifasi dalam memanfaatkan wilayah penangkapan yang menggunakan alat tangkap rumpon. Akhirnya formasi relasi kuasa yang konfliktual dalam waktu dan kondisi tertentu dapat berubah menjadi relasu kuasa yang cenderung kerjasama. Walaupun masih di bayangbayangi oleh konflik. 


\section{b. Relasi Kuasa Nelayan Lokal dan Nelayan Dari Luar (Nelayan Banten)}

Relasi kuasa nelayan lokal dengan nelayan dari luar lebih kepada kerjasama dan menuju kepada hubungan yang konfliktual. Hubungan nelayan lokal dengan nelayan dari luar yang berada di wilayah Kabupaten Lebak Banten tepatnya dengan nelayan Binuangen sudah lama terjalin hubungan baik dalam kepentingan wilayah penangkapan ikan maupun berkaitan dengan pemasaran hasil tangkapan yang di jual belikan di wilayah Tempat Pelelangan Ikan Palabuhanratu. Nelayan Palabuhanratu sudah sering menangkap ikan dan melakukan bongkar ikan di wilayah dramaga Binuangen begitu juga dengan nelayan Palabuhanratu sampai sekrang apabila ada hasil tangkapan dari Kapal Purse Seine itu menandakan dari nelayan Binuangen Banten. Hubungan kersjasama dalam kekuasaan ekonomi politik yang bertujuan untuk melakukan pengelolaan dan pemanfaatan sumber daya laut Palabuhanratu. Nelayan dari luar bukan saja dari wilayah banten yang secara administrasi sebelum menjadi provinsi tersendiri bahwa Banten merupakan bagian dari wilayah provinsi Jawa Barat, sehingga hubungan antara nelayan lokal dengan nelayan dari luar Banten sudah lama terjalin. Nelayan dari luar tidak saja dari Banten tetapi terdapat pula nelayan dari jakarta dan Cilacap (Jawa) yang ikut memanfaatkan dan mengelola sumber daya laut, perbedaan dan persamaan alat tangkap antara nelayan lokal dengan nelayan dari luar Jakarta dan Cilacap (Jawa) lebih mengarah kepada hubungan yang konfliktual, karena memiliki alat tangkap yang sama dan alat tangkap yang berbeda pun dapat menimbulkan hubungan konfliktual. Nelayan lokal lebih banyak ada di alat tangkap kincang dan Payang. Sedangkan, nelayan dari Luar yang dari Jakarta dan Cilacap (Jawa) kebanyakan berada di kapal-kapal besar, tetapi sebagian di antara mereka ada yang memanfaatkan alat tangap payang dalam memanfaatkan sumber daya laut.

\section{c. Relasi Kuasa Nelayan Pendatang (Etnis Bugis) dan Nelayan Dari Luar (Nelayan Banten)}

Nelayan pendatang dari etnis Bugis sebetulnya lebih dahulu memanfaatkan wilayah laut yang berada di wilayah Binuangen Banten. Selanjutnya, ada beberapa nelayan yang dari etnis bugis yang sebelumnya memanfaatkan dramaga dan wilayah yang berada di Binuangen dan sudah dekat dengan nelayan lokal yang ada di Binuangen yang secara etnisitas bahwa nelayan Binuangen sama dengan Nelayan dari Palabuhanratu. Walaupun, dalam perkembangannya banyak nelayan dari Sulawesi yang lasungusng datang ke wilayah laut Palabuhanratu. Ada beberapa nelayan Bugis yang memberikan alasan bahwa terkait dengan alasan memanfaatkan wilayah laut dan pesisir $P$ alabuhanratu terkait dengan ekonomi yang berkaitan dengan pemasaran yang tidak membutuhkan biaya yang cukup tinggi. Walaupun, masalahnya di wilayah Palabuhanratu ketika melakukan pengangkatan ikan banyak yang ikut mengambil ikan atau meminta ikan, tetapi walaupun pengelolaan belum menjamin rasa aman 100 persen, setidaknya secara ekonomi dalam melakukan pemasaran atau distribusi ikan cukup baik. Hubungan relasi kuasa antara nelayan pendatang dengan nelayan dari luar lebih mengarah kepada kerjasama.

\section{d. Relasi Kuasa Nelayan dan Pengelola PLTU}

Resistensi dalam hubungan patron klien terjadi ketika ada ketidakadilan atau relasi kekuasaan yang tidak seimbang antara pemilik modal dengan nelayan, begitu juga relasi kuasa pemilik kapal dengan buruh nelayan. Hubungan patron klien tersebut dapat berguna untuk mengungkap relasi kuasa antara kelas penguasa dengan kelas bawah. Melalui bukunya "Domination and The Arts of Resistance: Hidden Transcript", Scott (1990) mengungkapkan dua konsep pola interaksi yang berbeda yaitu: Pertama, public transcipts merupakan pola interaksi, sikap, prilaku dan pencitraan yang diproduksi oleh kalangan penguasa, dimana di ruang publik, kelas penguasa berupaya membangun legitimasi kekuasaan dan mengendalikan pola kehidupan yang dijalani bersama. Sementara kelas bawah sering menunjukkan kepatuhan kepada aturan-aturan, norma-norma, dan kebijakan-kebijakan yang dibentuk oleh kelas penguasa. Diskursus pada ruang publik cenderung dikendalikan oleh kelas dominan. Kedua, Hidden Transcript merupakan pola interaksi informal yang dibangun kelas bawah di luar pengawasan dan kendali kelas penguasa dan dapat menjadi melatar belakngi munculnya resistensi. Resistensi ini dapat berbentuk hidden transcipt atau public transcipt.

Perlawanan nelayan di Pelabuhanratu cenderung perlahan-lahan dan senyap-senyap, hal tersebut terjadi karena kurang kautnya sistem kelembagaan informal yang dimiliki oleh 
setiap kelompok nelayan di pelabuhanratu, sehingga keputusan pemerintah menjadi final dalam menentukan aktivitas nelayan. Akan tetapi, walaupun demikian bukan berarti nelayan tidak memiliki kemampuan untuk melakukan perlawanan baik di ranah aktivitas penangkapan maupun di ranah kebijakan. Informan nelayan lokal mengungkapkan:

"Saleresnamah, eta PLTU teh, sanes bade dibangun di Pelabuhanratu, tapi di daerah Ujung Genteng Sukabumi, tapi aya tindakan ti nelayan Ujung Genteng. Anu akhirna di bangun weh di Pelabuhanratu. Sabenerna sanes teu aya tindakan ti nelayan Pelabuhanratu. Atos sababaraha kali demo ka PLTU tapi tetep da teu aya kakuatan. Pemerintah anu ngatur sadayana dina ngabangun PLTU eta, ayenamah nelayan aya anu kerjasama ngaberesken zonasi atanapi ngabagi wilayah antara nelayan jeng PLTU. Salain eta, sabenerna PLTU teu aya guna na kange orang Pelabuhanratu"

Informan Nelayan Pendatang mengungkapkan: "Bagi kami hadirnya PLTU pelabuhanratu sudah membatasi wilyah atau zonasi penangkapan. Reaksi yang kami lakukan yaitu dengan mendekati jajaran pemangku kebijakan dan meminta kembali untuk mengtur wilayah penangkapan ikan di laut Pelabuhanratu. Akhirnya, wilayah laut Selatan yang awalnya digunakan untuk penangkapan ikan berpindah ke wilayah barat karena adanya aktivitas transfortasi laut oleh pihak PLTU, untuk mengangkut batubara"

Informan Nelayan Dari Luar mengungkapkan: "Alattangkap seeranu rusak, urang sadayana ngelakuken demo ka PLTU, anu jadina pimpinan PLTU diganti, tapi asa tetap sarua bae. Lauttetep tercemaridan kapalkapal pengangkut batubara semakin banyak, terpaksa daerah newak lauk jadi pindah, tapi urang tetep arek mempertahanken ieu wilayah laut, kujalana menta izin penangkapan ke pihak pengelolan laut Pelabuhanratu yaitu PPN pelabuhanratu jeng Dinas kelautan dan perikanan pelabuhanratu"

Hasil dari wawancara dengan informan yang melakukan aktivitas di wilayah laut Pelabuhanratu menunjukkan bahwa: Perlawanan yang dilakukan nelayan cenderung terjadi secara sendiri-sendiri, dimana setiap kelompok nelayan memiliki cara dan ide sendiri dalam melakukan reaksi terhadap PLTU, terutama nelayan dari luar yang melakukan demonstrasi hanya kelompoknya saja. Nelayan pendatang lebih memiliki kekuasaan yang lebih karena didukung oleh alat tangkap atau teknologi yang lebih moderen. Bentuk-bentuk perlawanan nelayan digambarkan dalam Tabel 3 .

Tabel 3. Kuasa Nelayan Pelabuhanratu Untuk Melawan.

Table 3. The Power of Fishers Pelabuhanratu To Fight.

\begin{tabular}{|c|c|c|}
\hline Aktor dan Perlawanan & Hidden Transcript & Public Transcripts \\
\hline $\begin{array}{l}\text { Nelayan Lokal/ } \\
\text { Local Fishers }\end{array}$ & $\begin{array}{l}\text { Terus menghujat hadirnya PLTU/Continue } \\
\text { to blaspheme the presence of PLTU }\end{array}$ & $\begin{array}{l}\text { Demonstrasi sampai terjadi pergantian } \\
\text { pimpinan PLTU Pelabuhanratu/ } \\
\text { Demonstration until the turn of } \\
\text { leadership of PLTU Pelabuhanratu }\end{array}$ \\
\hline $\begin{array}{l}\text { Nelayan Pendatang/ } \\
\text { Fishers Newcomer }\end{array}$ & $\begin{array}{l}\text { Pelan-pelan melukan kmunikasi dengan } \\
\text { nelayan dari luar dan nelayan asli/Slowly } \\
\text { communicate with outside fishermen and } \\
\text { native fishermen }\end{array}$ & $\begin{array}{l}\text { Diplomasi sampai memunculkan } \\
\text { kebijakan baru tentang zonasi } \\
\text { penangkapan yang berpindah karena } \\
\text { dipakai oleh transfortasi PLTU/ } \\
\text { Diplomacy to emerge a new policy } \\
\text { on catching zoning that is shifting } \\
\text { as it is being used by power plant } \\
\text { transfortations }\end{array}$ \\
\hline $\begin{array}{l}\text { Nelayan Dari Luar/ } \\
\text { Fishers From Outside }\end{array}$ & $\begin{array}{l}\text { Melakukan tindakan-tindakan perlawanan } \\
\text { secara diam-diam terhadap PLTU, } \\
\text { sehingga menimbulkan demonstrasi } \\
\text { nelayan dari luar terhadap PLTU/ } \\
\text { Perform silent resistance actions against } \\
\text { the steam power plant, leading to } \\
\text { demonstrations from outside fishers to } \\
\text { PLTU }\end{array}$ & Demonstrasi/Demonstration \\
\hline $\begin{array}{l}\text { PLTU Pelabuhanratu/ } \\
\text { PLTU Manager }\end{array}$ & $\begin{array}{l}\text { Bermaian melalui kebijakan/ Working } \\
\text { through policy }\end{array}$ & $\begin{array}{l}\text { Memberikan bantuan kepada kelompok } \\
\text { nelayan tertentu/Provide assistance to } \\
\text { certain fishing groups. }\end{array}$ \\
\hline
\end{tabular}


Relasi kekuasaan antara nelayan dengan Pengelola PLTU 2 Jabar Palabuhanratu sudah lama terjadi mulai dari proses rencana pembangunan. Terjadi relasi kuasa dalam bentuk perlawanan nelayan kepada pihak PLTU, disamping karena perbedaan kepentingan di antara dua aktor, juga masyarakat nelayan khawatir dengan kehadiran PLTU dapat memberikan dampak ekologi bagi sumber daya kelautan dan perikanan. Selain itu, Pembangunan PLTU terkait penempatan pelabuhan tempat perahu Tongkang pengangkut batubara masih menjadi permasalahan serius di antara nelayan dan PLTU. Dampak dari perbedaan kepentingan dan perbedaan kekuasaan yang dimiliki antara kelompok nelayan dengan pengelola PLT telah menyebabkan terjadinya relasi kuasa yang berbentuk perlawanan dan sudah sampai ke tahap demonstrasi, bahkan masyarakat nelayan diminta untuk membuat laporan terkait dengan dampak lingkungan yang berkaitan dengan adanya indikasi limbah PLTU Palabuhanratu ke wilayah laut Palabuhanratu.

\section{e. Relasi Kuasa Nelayan Dengan Pihak Pemerintah}

Negara merupakan pihak yang memberikan legitimasi (legitimation) atas hadirnya indsutri atau pltu dalam mengeksploitasi sumber daya pesisir dan laut dengan menetapkan berbagai regulasi/ kebijakan yang terkait dengan penguasaan dan pengelolaan sumber daya pesisir dan perairan laut. seperti peraturan Peraturan Presiden Republik Indonesia nomor 45 tahun 2014 tentang perubahan ketiga atas Peraturan Presiden nomor 71 tahun 2006 tentang penugasan kepada PT. Perusahaan Listrik Negara (Persero) untuk melakukan percepatan pembangunan pembangkit tenaga listrik yang menggunakan batubara. peraturan presiden republik indonesia nomor 4 tahun 2016 tentang percepatan pembangunan infrastruktur ketenagalistrikan. Peraturan pemerintah nomor 71 tahun 2006 tentang penugasan kepada PT. Perusahaan Listrik Negara (Persero) untuk melakukan percepatan pembangunan pembangkit listrik yang menggunakan batubara.

Adanya peraturan khusus yang mengatur tentang pemberian izin kepada pihak PLN untuk melakukan pembangunan PLTU. Saat ini peran negara setidaknya ada dalam peraturan tersebut sudah mengalami perubahan, perubahannya yaitu Peraturan Presiden Republik Indonesia nomor 59 tahun 2009 tentang perubahan atas peraturan presiden nomor 71 tahun 2006 tentang penugasan kepada PT. Perusahaan Listrik Negara (Persero) untuk melakukan percepatan pembangunan pembangkit tenaga listrik yang menggunakan batubara. Selain itu, peranan negara ada dalam peraturan tentang pengelolaan sumber daya kelautan dan perikanan termasuk sumber daya pesisir. Seperti yang tertuang dalam undangundang republik indonesia nomor 32 tahun 2014 tentang kelautan, peraturan daerah provinsi jawa barat Nomor: 7 tahun 2011 Tentang Pengelolaan perikanan dan Kelautan.

Relasi kuasa antara nelayan dengan pihak otoritas lebih mengarah kepada kerjasama atau negosiasi dalam proses pemanfaatan dan pengelolaan sumber daya laut di Palabuhanratu. dengan adanya, kebijakan-kebijakan yang dikeluarkan oleh pihak pemerintah pihak nelayan sebagai pengguna wajib mengikuti peraturanperaturan formal ataupun peraturan yang disepakati antara nelayan dengan pihak pemerintah. Pihak pemerintah yang mewakili dalam pengelolaan sumber daya laut Palabuhanratu, terbagi dua yaitu pertama pihak Pelabuhan Perikanan Nusantara (PPN) Palabuhanratu sebagai pihak perwakilan dari pemerintah pusat dan Dinas Kelautan dan Perikanan kabupaten Sukabumi sebagai perwakilan dari pemerintah Daerah.

Relasi antara nelayan dengan pihak pemerintah tidak selamanya terjadi dalam bentuk konfliktual tetapi lebih banyak terjadi dalam negosiasi atau kerjasama sebagaimana yang dibuktikan dari hasil penelitian Herwening (2003), diamana adanya perubahan alat tangkap nelayan di Palabuhanratu dan banyaknya nelayan pendatang dan nelayan dari luar ikut serta dalam memunculkan konlfik sosial dikalangan nelayan Palabuhanratu, sehingga peran dari pihak pemerintah sangat dibutuhkan. Dengan demikian pemerintah menjadi salah satu aktor yang memiliki hubungan negosiasi bagi semua kalangan nelayan di Palabuhanratu.

\section{PERAN LEMBAGA SWADAYA MASYARAKAT}

Nelayan dan industri (pengelola PLTU) merupakan aktor yang saling berhadap-hadapan karena memiliki kepentingan untuk penggunaan sumber daya pesisir dan sumber daya kelautan dan perikanan. Kehadiran PLTU, melakukan penguasaan sumber daya kelautan dan perikanan di wilayah Palabuhanratu Sukabumi telah mengurangi 
bahkan menghilangkan wilayah pelabuhan dan wilayah penangkapan nelayan, terutama wilayah muara sungai dan pesisir yang digunakan oleh PLTU dan wilayah laut yang di kuasai untuk transfortasi laut dan tempat pelabuhan kapal-kapal Tongkang di atas 3 mil laut. Keberadaan PLTU di wilayah Palabuhanratu mengundang munculnya banyak pihak untuk memperjuangkan berbagai kepentingan dalam pengelolaan sumber daya kelautan dan perikanan di wilayah Palabuhanratu kabupaten Sukabumi.

LSM yang ikut berperan serta dalam menyelesaikan permasalahan antara pihak nelayan dengan Pengelola PLTU dan LSM juga yang ikut memperhatikan kondisi lingkungan di sekitar wilayah pesisir Palabuhanratu dan wilayah Laut Kabupaten Sukabumi yang dilintasi atau digunakan oleh PLTU 2 Jabar Palabuhanratu Kabupaten Sukabumi. Tetapi, faktanya ada LSM yang berpihak kepada Nelayan ada juga LSM yang berpihak kepada pihak pengelola PLTU. Selin itu, dilapangan ditemukan organisasi yang bukan LSM juga bukan masuk ke aktor pihak pemerintah.

LSM Pam Nappas merupakan organisasi nirlaba lokal, yang bergerak di bidang lingkungan dan memiliki kepedulian kepada kondisi masyarakat sekitar. Organisasi ini cenderung berbeda paham dengan pemrakarsa, yaitu dalam hal pembuangan materi hasil kerui, mereka merekomendasikan dibuang ke darat. LSM Paguyuban Masyarakat Nelayan dan Petani (Pam Nappas) Palabuhanratu Sukabumi, yang secara terang-terangan melakukan penolakan terhadap keinginan pihak PLTU yang berencana untuk membuang limbah pasir di wilayah laut Palabuhanratu. Selain itu, LSM Pam Nappas ikut serta dalam menyelesaikan permasalahan lingkungan yang terindikasi bahwa ada limbah PLTU yang mengalir ke wilayah laut Palabuhanratu. Aliran limbah yang diketahui oleh masyarakat hanya satu aliran dan diakui oleh pihak PLTU. Tetapi, pihak LSM dan masyarakat nelayan masih menduga bahwa masih ada aliran limbah yang mengalir ke wilayah laut dan sungai Cimandiri.

LSM PamNappas menjalin relasi dengan pihak-pihak organisasi yang ada di Palabuhanratu. Hubungan terbangun karena adanya jaringan kekuasaan berupa pengetahuan tentang wacana dampak dari limbah pasir dan limbah batubara PLTU yang dapat merugikan masyarakat terutama masyarakat nelayan, karena tercemarnya air laut. relasi dibangun dengan organisasi Himpunan Nelayan Seluruh Indonesia (HNSI), Himpunan
Mahasiswa Islam (HMI) Palabuhanratu, Pergerakan Mahasiswa Islam Indonesia (PMII), dan Angkatan Muda Siliwangi (AMS).

\section{PENUTUP}

Kelompok kepentingan dalam pengelolaan dan pemanfaatan sumber daya laut Palabuhanratu memiliki kepentingan dan kekuasaan yang berbedabeda sehingga untuk menyelesaikannya tidak semudah dengan terus mengeluarkan berbagai kebijakan dari pemerintah, tetapi harus memahami berbagai karakteristik kekuasaan ekonomi politik yang dimiliki oleh masing-masing aktor. Aktor yang terdapat di Palabuhanratu yaitu: Pemerintah Kabupaten Sukabumi sebagai representatif dari negara, Pengelola PLTU (Swasta), Lembaga Swadaya Masyarakat (LSM) Pam Nappas, wisata bahari, dan nelayan. Aktor-aktor yang ada dalam pengelolaan dan pemanfaatan sumber daya laut Palabuhanratu menggunakan kekuasaannya, untuk dapat memanfaatkan atau mengelola sumber daya laut agar terhindar dari kerusakan lingkungan atau kerusakan sumber daya kelautan dan perikanan.

Relasi kuasa nelayan lokal dengan nelayan pendatang cenderung bersifat negosiasi. Nelayan lokal dengan nelayan dari luar lebih kepada konflik. Nelayan pendatang dengan nelayan dari luar terjadi dalam ranah negosiasi. Sedangkan, relasi kuasa nelayan dengan pengelola PLTU lebih kepada bentuk konflik dan perlawanan dengan menggunakan jenis kekuasaan yang berbeda-beda. Nelayan lokal lebih memiliki kekuasaan identitas, nelayan pendatang dengan kekuasaan relasi sosial, modal dan teknologi, sedangkan nelayan dari luar dengan kekuasaan otoritas mendapatkan ijin dari pengelola PPN Palabuhanratu dan pemerintah Kabupaten Sukabumi melalui dinas kelautan dan perikanan.

Implikasi kebijakan yang dapat diberikan dalam mengatasi permasalahan relasi kuasa yang tidak setara di antara aktor-aktor dalam pengelolaan dan pemanfaatan sumber daya laut di Palabuhanratu. Pertama, dapat memberikan informasi dalam membuat kebijakan yang berkaitan dengan permasalahan wilayah pesisir, zonasi laut, dan penyelesaian adanya tudingan indikasi pencemaran limbah, sehingga dapat memperjelas wilayah laut yang digunakan oleh pengelola PLTU dan penyelesaian permasalahan, terkait antara kelompok nelayan maupun antara nelayan dengan Pengelola PLTU Palabuhanratu. Kedua, penyelesaian degradasi lingkungan 
dapat melibatkan semua aktor, baik aktor negara, swasta (PLTU Palabuhanratu), Lembaga Swadaya Masyarakat (LSM), dan aktor lokal. Aktor-aktor yang ada di komunitas pemanfaat sumber daya laut Palabuhanratu, dapat bersamasama menyelesaikan permasalahan dengan menghadirkan berbagai pengaturan yang berkaitan dengan pengelolaan dan pemanfaatan sumber daya laut.

\section{UCAPAN TERIMA KASIH}

Penelitian ini merupakan salah satu bagian dari tesis penelitian Magister Program Studi Sosiologi Pedesaan Pascasarjana Institut Pertanian Bogor (IPB), dibawah bimbingan Dr. Arif Satria, S.P., M.Si dan Dr. Ir. Saharuddin, M.Si. Penelitian in didukung dan mendapatkan pembiayaan oleh Beasiswa Lembaga Pengelola Dana Pendidikan (LPDP). Selain itu, ucapan terimakasih kepada pengelola jurnal sosial kelautan dan ekonomi yang membantu memperbaiki penulisan. Kepada para nelayan Palabuhanratu dan kepada pihak-pihak yang memberikan kontribusi dan dukungan dalam penyelesaian penelitian, sehingga tulisan ini dapat di terbitkan, baik kepada pihak yang disebutkan ataupun pihak-pihak yang tidak dapat disebutkan.

\section{DAFTAR PUSTAKA}

[BPS] Badan Pusat Statistik Indonesia. 2016. Statistik Sumber Daya Laut Dan Pesisir 2016. Jakarta (ID): Badan Pusat Statistik Indonesia.

[DKP] Direktorat Kelautan dan Perikanan. 2014. Kajian Strategi Pengelolaan Perikanan Berkelanjutan. Jakarta (ID): Direktorat Kelautan dan Perikanan.

[FOA] Food and Agriculture Organization. 2000. Conflict and natural Resource Management. Rome (IT): Food and Agriculture Organization.

[PPN] Pelabuhan Perikanan Nusantara Palabuhanratu.2017. Statistik Pelabuhan Perikanan Nusantara Palabuhanratu Tahun 2017. PPN Palabuhanratu.

Bryant, R.L dan S. Bailey. 1997. Third World Political Ecology. Routledge: London and New York.

Bryant, R.L. 1998. Power, Knowledge, and Political Ecology in the third world: a Review. Journal Proggress in Pshysical Geography 22, $1 \mathrm{pp}$ 79-94.

Buckles, D. 1999. Cultivating Peace; Conflict and
Collaboration in Natural Resources Management. International Development Research Center (IDRC) in collaboration with The World Bank Institute. Ottawa. Canada.

Febryano, I.G., D. Suharjito, D. Darusman dan C. Kusmana. 2015. Aktor dan Relasi Kekuasaan Dalam Pengelolaan Mangrove Di Kabupaten Pesawaran. Jurnal Analisis Kebijakan Kehutanan. Vol. 12 No.2.

Herwening, E. 2003. Modernisasi Perikanan Dan Potensi Konflik di Palabuhanratu. Fakultas Ekologi Manusia. Institut Pertanian Bogor. Program Magister Sosiologi Pedesaan. Bogor.

Kurniawan, D. 2012. Analisis Dampak Pembangunan Pembangkit Listrik 10.000 MW Terhadap Perekonomian Indonesia [Tesis]. Jakarta (ID): Universitas Indonesia.

Miles, M.B., A.M. Huberman dan J. Saldana. 2014. Qualitative Data Analysis: AMethods Sourcebook. United States of America (US): Arrizona State University.

Priyatna F.N., R.A. Kinseng dan A. Satria. 2013. Akses dan strategi aktor-aktor dalam pemanfaatan sumber daya waduk Djuanda. J Sosek KP Vol. 8 (1), pp. 1-9.

Ribot, J.C dan N.L. Peluso. 2003. A theory of access. Rural Sociology, Vol. 68 No 2, pp. 153-181.

Rilus, A.K. 2007. Konflik-Konflik Sumber daya Alam di Kalangan Nelayan di Indonesia. Sodality. ISSN: 1978-4333, Vol. 01, No. 01.

Satria, A. 2015. Pengantar Sosiologi Masyarakat Pesisir. Jakarta (ID): Yayasan Pustaka Obor Indonesia.

Scott, J.C. 1990. Dominations and The Art of Resistance. Yale Univercity.

Wegenast, T. and Schneider, G. 2016. Ownership matters: Natural resources property rights and social conflict in Sub-Saharan Africa. Political Geography. 61 (2017) 110-122.doi: 10.1016/j. polgeo.2017.07.007. 